\title{
Ackerman's higher lawmaking in comparative constitutional perspective: Constitutional moments as constitutional failures?
}

\author{
Sujit Choudhry*
}

Bruce Ackerman speaks with two voices. While he is one of the most prominent students of comparative constitutionalism in the U.S. legal academy. Ackerman is better known for his imaginative theory of American constitutional development. In the latter voice, Ackerman observes that, notwithstanding a remarkable continuity of governance, U.S. constitutional history falls into three distinct regimes. He argues that the transitions between these different constitutional regimes, inasmuch as they have failed to comply with the Constitution's written rules for its own amendment, have taken place through a process of "higher lawmaking." There is an underlying tension between this voice of Ackerman's and the other one, which expounds on the relevance of comparative analysis for constitutional scholarship. While Ackerman the comparativist lambastes U.S. constitutional scholars for their parochialism, in We the People he calls on American constitutional scholars to ground theories of the Constitution in indigenous political practice. This paper attempts to reconcile the two strands of Ackerman's work, focusing on the "constitutional moment"Ackerman's central contribution to the study of American constitutional change-and applying it to other countries, specifically, Canada. The comparative constitutional research questions are whether other systems experience constitutional moments, and what we can learn about these moments by studying them inside and outside the United States.

\section{Introduction: Ackerman's two voices}

Will the real Bruce Ackerman stand up? Is there a real Bruce Ackerman-or only a bunch of multiple, if partial, identities that don't add up over time? ${ }^{21}$

\footnotetext{
* Faculty of law, University of Toronto. Thanks to Bruce Ackerman, who generously disagrees with my rereading of his work, and to Chris Eisgruber, Bill Eskridge, Jean-François Gaudreault-Desbiens, Ran Hirschl, Ed lacobucci, Darlene Johnston, Tony Keller, Karen Knop, Sandy Levinson, Patrick Macklem, Mayo Moran, Jennifer Nedelsky, Kent Roach, Carol Rogerson, Kim Scheppele, David Schneiderman, Ayelet Shachar, Mark Tushnet, Ernie Weinrib, and Lorraine Weinrib for helpful comments. Eric Adams provided skilled research and editorial assistance. This paper is part of a longer work in progress, entitled Retuinking CoMparative Constitutional Law. Email: sujit.choudhry@utoronto.ca Web site: wmw.law.utoronto.ca/faculty/choudhry
}

${ }^{1}$ Bruce Ackerman, Rooted Cosmopolitanism, 104 ETHIcs 516. 517 (1994). 
Bruce Ackerman is a constitutional scholar who speaks with two voices. For over a decade, he has been one of the most prominent scholars of comparative constitutionalism in the American legal academy. His 1992 book, The Future of Liberal Revolution, made the case for the viability of liberal democratic constitutionalism in the former communist countries of Eastern Europe, even though their experiences with liberal democracy were distant or nonexistent and their revolutionary political transitions were seemingly antithetical to the liberal constitutional ideal. ${ }^{2} \mathrm{He}$ continued this work in 1997, examining the proliferation of written constitutions and the growth of judicial review, which he termed "the rise of world constitutionalism." ${ }^{3}$ More recently, he made an extended argument in the Harvard Law Review for the superiority of a "constrained parliamentarism" over American-style separation of powers as a method for the allocation of institutional power and for fashioning relationships between the executive and legislative branches. ${ }^{4}$ Finally, in the wake of 9/11, Ackerman has argued for the adoption of an "Emergency Constitution" that would strengthen congressional oversight of presidential actions during emergencies; he constructs this model of constitutionalism on the basis of lessons to be learned from the emergency provisions in constitutions of a wide number of jurisdictions. ${ }^{5}$

However, Ackerman arguably is far better known, even outside the United States, for his imaginative theory of American constitutional development. ${ }^{6}$ Ackerman's theory has both descriptive and normative aspects. Descriptively, he argues that, notwithstanding a remarkable continuity in governing constitutions, the American Constitution has undergone tremendous change since the adoption of the federalist Constitution. American constitutional history can be sharply divided into distinct regimes, each defined by a unique "matrix of institutional relationships and fundamental values."7 Ackerman's original

\footnotetext{
${ }^{2}$ Bruce Ackerman, The Future of Liberal Revolution (Yale Univ. Press 1992).

${ }^{3}$ Bruce Ackerman. The Rise of World Constitutionalism, 83 VA. L. REv. 771, 772 (1997).

${ }^{4}$ Bruce Ackerman, The New Separation of Powers, 113 HARv. L. Rev. 633, 665 (2000).

${ }^{5}$ Bruce Ackerman, Before the Next Attack: Preserving Civil Liber ties in an Age of Terrorism (Yale Univ. Press 2006).

${ }^{6}$ Bruce Ackerman, The Storrs Lectures: Discovering the Constitution, 93 YALE L.J. 1013 (1984); Bruce Ackerman, Transformative Appointments, 101 Harv. L. Rev. 1164 (1988); Bruce Ackerman. Constitutional Politics/Constitutional Law, 99 YaLE L.J. 453 (1989); Bruce Ackerman \& Neal Katyal, Our Unconventional Founding. 62 U. CH. L. Rev. 475 (1995); Bruce Ackerman \& David Golove. Is NAFTA Constitutional?, 108 Harv. L. Rev. 799 (1995); 1 Bruce Ackerman, We the People: Foundations (Harvard Univ. Press 1995) [hereinafter Ackerman, Foundations]; 2 Brucb Ackfrman, We the People: Transformations (Harvard Univ. Press 2001) [hereinafter Ackrrman, Transformations]; Bruce Ackerman, 2006 Oliver Wendell Holmes Lectures: The Living Constitution, 120 HaRv. L. Rev. 1737 (2007) [hereinafter Ackerman, Holmes Lectures].
}

${ }^{7}$ ACKERMAN, Foundations, supra note 6, at 59. 
contribution is his view that the transitions between constitutional regimes have taken place through a process of "higher lawmaking" involving intense and relatively brief periods of focused and public-spirited deliberation by the American people. These transitional periods have other defining features: a complex but determinate pattern of interaction between America's governing institutions, which is recognized by both those institutional actors and the public as unique to transitions between constitutional regimes; and, most arrestingly, a failure to comply with the written legal rules governing constitutional amendment. Ackerman argues that, normatively, the American story of constitutional change- "dualist democracy"-is a practical response to the limited capacity of citizens in a modern democracy to engage in democratic self-government, since it expects them to engage in collective political choice relatively rarely. And since it is only at these "constitutional moments" that the American people have truly spoken, and because there are clear criteria to determine when such moments have occurred, dualist democracy also offers a path out of the thicket of the countermajoritarian objection to judicial review. Because of its scope and ambition, Ackerman's theory has led one scholar to suggest that he "undoubtedly" belongs in the "pantheon of constitutional theorists."8

Although Ackerman's constitutional scholarship has been widely discussed, what has escaped observation is that the two strands of his work are deeply in tension, reflecting an internal conflict about the relevance of comparative analysis for constitutional scholarship. Consider Ackerman the comparativist. In characteristically polemical fashion, Ackerman lambastes American constitutional scholars for their "emphatic provincialism" and their "astonishing indifference" toward constitutional developments abroad. ${ }^{9}$ He derides American scholars for "grappling with the original understanding of the Constitution of 1787, the Bill of Rights, and the Reconstruction Amendments with new intensity"10 at the expense of comparative scholarship. The intellectual agenda for American scholars should be to "learn to think about the American experience in a different way ... to look upon the American experience as a special case, not as the paradigmatic case." 11 The benefit of situating the American constitutional system in comparative perspective, argues Ackerman, is that it "helps American constitutional lawyers place their own tradition in critical perspective," thereby enabling them to step back from the audacious claim that the American system is "an inspiring beacon for liberal democrats everywhere."12

\footnotetext{
${ }^{8}$ James E. Fleming, We the Unconventional American People, 65 U. CHI. L. Rev. 1513, 1515 (1998).

${ }^{9}$ Ackerman, supra note 3, at 772-773.

${ }^{10}$ Id. at 773 .

"Id. at $774-775$.

${ }^{12}$ Ackerman, supra note 4 , at 642 .
} 
These criticisms surely apply to Ackerman's own work on the U.S. Constitution, which focuses entirely on the United States and, methodologically, is grounded self-consciously in the concrete details of U.S. constitutional and political history, with only scattered and brief comparative references. It is, therefore, striking that at the very outset of Foundations, Ackerman argues against the use of "European ... conceptual frameworks" in a well-known passage:

To discover the Constitution, we must approach it without the assistance of some philosophical guide imported from another time and place. Neither Aristotle nor Cicero, Montesquieu nor Locke, Harrington nor Hume, Kant nor Weber, provides the key. Americans have borrowed much from such thinkers, but they have also built up a genuinely distinctive pattern of constitutional thought and practice. ${ }^{13}$

Ackerman's target is the reliance by normative constitutional theorists on European political thought. But by issuing a nationalist call to U.S. scholars to ground their theories of the U.S. Constitution in indigenous political practice, his methodological choice also rules out the resort to comparative legal materials. Ackerman goes on say, "we must look inward, not outward"14__advice he follows in Transformations, notwithstanding its appearance after the comparative turn in his own scholarship. To be sure, Ackerman does situate his project comparatively. In Foundations, he briefly compares the design of the constitutions of the U.S., United Kingdom, and Germany, suggesting that the German is "foundationalist," because certain basic values are entrenched and placed beyond the reach of constitutional revision; the British is "monist," because parliamentary supremacy means that no fundamental values legally restrain legislative decision making; and the U.S. design is "dualist," because binding legal constraints on governments are open to democratic revision in their entirety. ${ }^{15}$ But his usual approach is to emphasize the uniqueness of the American constitutional experience without the benefit of substantial comparisons, if any. The comparative perspective is, at best, a superfluous afterthought that does no real work, a rhetorical footnote to a complex and extended argument.

Reconciling the two strands of Ackerman's scholarly agenda would appear to be an unpromising project, given Ackerman's firm anchoring of his theory of constitutional change in the particularities of American constitutional history. But such an exercise, if framed the right way, can prove to be fruitful. Ackerman's central contribution to the study of American constitutional

\footnotetext{
${ }^{13}$ ACKerman, Foundations, supra note 6, at 3.

${ }^{14}$ Id. at 33.

${ }^{15} 1 d$. at 8-16.
} 
change is the idea of the constitutional moment. The question posed here is whether other constitutional systems experience constitutional moments, and what we can learn about constitutional moments from studying them both inside and outside the United States. ${ }^{16}$

This comparative move is possible only if we first, and fundamentally, recast our understanding of constitutional moments. The critical literature prompted by We the People has persuasively argued that Ackerman has failed to adduce sufficient evidence to demonstrate that political actors were selfconsciously engaged in a process of higher lawmaking, taking place outside the normal constitutional process, that they perceived to be legal nonetheless. However, if shorn of this unsustainable empirical claim, at the core of constitutional moments is the following phenomenon - an extralegal constitutional change, prompted by the failure of formal rules of constitutional amendment that are designed to constitute and regulate constitutional politics without becoming part of it. Those rules fail in situations where they cannot perform their central function, which is to channel debates over constitutional change through procedures that yield institutional decisions that political actors accept as authoritative. To perform this function, the rules for constitutional amendment must be regarded as standing outside the terrain of substantive constitutional politics and as neutral among the competing constitutional positions in play. However, constitutional decision procedures themselves are far from substantively neutral and reflect competing conceptions of the very sorts of values that are the gist of constitutional politics. Constitutionalism depends, then, on suspending political judgment - with respect to the rules governing constitutional amendment-in order to purchase political settlement. This attitude will become most difficult to sustain when those rules reflect one of the competing, substantive constitutional positions on the table - at special moments of constitutive constitutional politics. At that point. because of the absence of accepted rules governing constitutional amendment, the constitutional system may collapse.

At least two of Ackerman's constitutional moments-the founding of the United States and Reconstruction-may have been such cases, because the rules governing constitutional amendment in the Articles of Confederation

\footnotetext{
${ }^{16}$ For other attempts to explore the comparative implications of the notion of the constitutional moment, see Peter Lindseth, Law, History and Memory: "Republican Moments" and the Legitimacy of Constitutional Review in France, 3 CoLum. J. Eur. L. 49 (1996/97); Sanford Levinson, Transitions, 108 Yale L.J. 2215 (1999); Neil Walker, After the Constitutional Moment, in A ConstTtuTtion For THE EuRoPEAN Union: First Comments on the 2003 Draft of the European Convention (Ingolf Pernice \& Miguel Maduro eds., Nomos Verlagsgesellschaft 2004), available at http://www.fedtrust.co.uk/uploads/ constitution/32_03.pdf (also published as Federal Trust Online Paper 32/03, 2003); Neil Walker, The Legacy of Europe's Constitutional Moment, 11 Constellations 368 (2004); András Sajó. Constitution without the Constitutional Moment: A View from the New Member States, 3 INT'L J. Const. L. (I•CON) 243 (2005); Mark Tushnet, Misleading Metaphors in Comparative Constitutionalism: Moments and Enthusiasm, 3 INT'L J. Const. L. (I•CON) 262 (2005).
} 
and article 5 reflected one of the substantive visions of the American political community at play in those episodes and were not, therefore, capable of regulating the process of constitutional change. Some of Ackerman's constitutional moments are, in reality, moments of constitutive constitutional politics, the very character of which leads to constitutional failure and breakdown. As a consequence, Ackerman should be read not as a theorist of constitutional change proceeding through mass democratic mobilization. Rather, Ackerman should be read as a theorist of constitutional crisis.

Thus reinterpreted, constitutional moments raise a new and interesting avenue for comparative inquiry that Ackerman does not pursue. I tackle this line of inquiry, here, through an examination of the decision of the Supreme Court of Canada in the Secession Reference. ${ }^{17}$ The Court was asked a narrow question on the constitutionality of unilateral secession by Quebec, a province in the Canadian federation, in the context of a highly charged disagreement between the Quebec and federal governments over the answer to that question and, indeed, on the role of the law itself in governing regime change. Unsurprisingly, the Court held unilateral secession to be unconstitutional. But, surprisingly, it established a new constitutional procedure specifically for secession that imposed a duty on the federal government to negotiate the terms of secession in good faith in the event of a favorable referendum vote by a clear majority of Quebecers in response to a clear question on secession.

Although it was framed as constitutional interpretation, what the Court actually did was to amend the Canadian Constitution without recourse to the formal procedures for constitutional amendment. Viewing the Secession Reference as the judicial component of a constitutional moment-understood as a constitutional failure - offers a new understanding of that episode. The impasse between the Canadian and Quebec governments over the secession of Quebec thrust the rules for constitutional amendment under the Canadian Constitution - the constitutional framework within which secession would occur-into constitutional politics. Those rules failed because they reflected a conception of the Canadian political community that the Quebec sovereignty movement challenged. Instead of providing a stable and uncontested framework for constitutional politics, those rules were drawn into constitutional politics and were unable to perform their basic function. This deep and profound constitutional failure offers a new explanation for the Court's otherwise puzzling move to amend the Canadian Constitution extralegally under the guise of constitutional interpretation-a move fueled by the political impossibility of adopting a formal constitutional amendment to craft an acceptable procedure to govern the secession of a province.

In sum, the reinterpretation of constitutional moments as extralegal responses to constitutional failure serves a number of intellectual goals.

\footnotetext{
${ }^{17}$ Reference re Secession of Quebec, [1998] 2 S.C.R. 217.
} 
It assists us in better understanding what is at the heart of Ackerman's account of extralegal changes to the American constitutional order. It defines a comparative constitutional research agenda of identifying and better understanding similar episodes of extralegal change in other legal systems. It brings the two halves of Ackerman's constitutional scholarship together, potentially yielding further dividends for the understanding of American constitutional development through comparative constitutional scholarship. Finally, it extends Ackerman's work on constitutional design to encompass rules for constitutional amendment and suggests that such rules may have a limited ability to constrain moments of constitutive constitutional politics, which goes to the very identity of a political community.

\section{Understanding constitutional moments}

\subsection{Ackerman's higher lawmaking system}

"The fulcrum of Ackerman's thesis is the problem of constitutional change."18 Ackerman begins by describing what he calls the "bicentennial myth," 19 whose key claim is one of American constitutional continuity. Whereas "[for] Europeans, the past two centuries are full of dramatic breaks and false starts,"20 according to the bicentennial myth, the American constitutional experience has been different. Although Americans, like Europeans, "have had ... [their] share of bitter conflict and profound transformation," these have occurred within a constitutional framework that has remained constant since the adoption of the Federalist Constitution in 1787. "While the French have run through five republics since 1789 , we have lived in only one."22

The problem with the bicentennial myth, says Ackerman, is that it does not fit the facts of American constitutional development, which has been one of dramatic constitutional change. He suggests that, notwithstanding the myth of constitutional continuity, American legal actors organize descriptions of their constitutional past around three pivotal moments-the founding, the Reconstruction, and the New Deal-that "stand out from the rest."23 Ackerman suggests that each of these momentous events launched a new constitutional regime, each with its own distinct constitutional structures and "fundamental values that are usually taken as the constitutional baseline

\footnotetext{
${ }^{18}$ Terrance Sandalow, Abstract Democracy: A Review of Ackerman's We the People, 9 Const. COMmENT $309,310(1992)$.

${ }^{19}$ Ackerman, Foundations, supra note 6 , at $34-57$.

${ }^{20}$ Id. at 34.

${ }^{21}$ Id.

${ }^{22}$ Id.

${ }^{23}$ Id. at 40.
} 
in normal political life." 24 The founding launched the early republic, which was characterized by a weak presidency, a national government with limited jurisdiction, and minimal protection for fundamental rights. Reconstruction marked the starting point of the middle republic, the core commitments of which included national citizenship based on equal rights of contract and property, restricted national power except to protect those rights of national citizenship, and congressional leadership within the national government. Finally, the New Deal constitutional settlement expanded national power to encompass plenary jurisdiction over economic regulation, brought an end to the aggressive judicial protection of rights of contract and property, and marked the rise of presidential leadership in the national government. ${ }^{25}$

As Ackerman fully acknowledges, the fact of dramatic constitutional change over time does not challenge the bicentennial myth per se, because the 1787 Constitution itself contemplates the possibility of constitutional amendment through article 5. The precise details are unimportant. What matters is the idea underlying the article, which proposes that constitutional amendments must satisfy one of the decision rules spelled out therein before they can become part of the Constitution and legally enforceable. The twenty-seven amendments to the U.S. Constitution bear vivid testimony to the fact that article 5 can be used successfully. Although the article does not state that it is the exclusive mechanism for constitutional amendment, one could plausibly argue, with Laurence Tribe, that it flows from the logic of a written constitution that it should be read in this way. ${ }^{26}$ If one accepts that a principal goal of a written constitution is to provide a set of clear restraints on the exercise of public power, dispensing with the rules governing constitutional amendment can subvert the goals of constitutionalism itself and lead to tyranny. Indeed, Ackerman recognizes this, describing one argument for amendment outside article 5 as "dangerous." 27 The implication is that amendments that fail to satisfy article 5 do not become part of the Constitution, at least not in that way. The fact that constitutional interpretation may eventually change constitutional meaning to accord with failed amendments does not retroactively change the legal significance of the failure to formally amend the Constitution.

But, as Ackerman acutely observes, this "legalist" explanation of constitutional change cannot account for the transitions between the three constitutional regimes. It was widely understood at the time that the adoption of the

\footnotetext{
${ }^{24}$ Id. at 59.

${ }^{25}$ In the most recent statement of his theory. Ackerman adds the "Civil Rights Revolution"-which he also terms the "Second Reconstruction"- to his list of constitutional moments, although not one that launched a new constitutional regime. Ackerman. Holmes Lectures, supra note 6.

${ }^{26}$ Lawrence Tribe, Taking Text and Structure Seriously: Reflections on Free-Form Method in Constitutional Interpretation, 108 HaRv. L. Rev. 1221, 1240-1244 (1995).

${ }^{27}$ Ackerman, Transformations, supra note 6, at 12.
} 
1787 Constitution did not comply with the procedure for constitutional amendment under the Articles of Confederation in several respects-its requirement of unanimous ratification by state legislatures obviously not being satisfied by the approval of nine state conventions. There were other potential illegalities as well. ${ }^{28}$ Now the illegality of the founding is hardly a novel point; indeed, it was a central concern of political actors at the time, as Ackerman vividly illustrates. ${ }^{29}$

Ackerman argues that the birth of the middle republic, especially the adoption of the Fourteenth Amendment, ${ }^{30}$ was also illegal under article 5. Once Congress proposed the Fourteenth Amendment, article 5 required ratification by two-thirds of the then-thirty-seven states-effectively granting twelve states a veto. Ten former members of the Confederacy rejected the amendment, seeming to assure that it would fail. To secure the passage of the amendment, Congress refused to seat a representative of any Southern state until that state had ratified the amendment and the amendment had received a sufficient number of ratifications to enter into force. These conditions appear to contravene article 5, which permits Congress to propose amendments to states for ratification but not to coerce states into accepting them. As Ackerman documents, the historical record reveals an acute awareness among political actors of the problematic legality of the Fourteenth Amendment. ${ }^{31}$ Finally, and most controversially, Ackerman argues that the "transformative opinions" 32 of the New Deal, which severely circumscribed constitutional protection for rights of property and contract and dramatically expanded the scope of national jurisdiction to regulate the economy, were such dramatic and sudden breaks with existing jurisprudence that they amounted to constitutional amendments.

At the heart of Ackerman's theory is the following problem: America's constitutional development contains many examples of fundamental, dramatic constitutional changes that appear to have occurred outside the textually prescribed procedures for constitutional amendment. Technically speaking, those constitutional changes are legally invalid. To the extent that these changes have marked the beginning of new constitutional regimes, Ackerman frames the central problem of American constitutional law as one of coming to terms with illegal regime change, or, as Commonwealth constitutional theorists would say, revolutionary legality. The easy solution to this difficulty is to deny there is any problem at all. If one works within a positivist understanding of the nature of a legal system, claims of extralegal constitutional change do only

\footnotetext{
${ }^{28}$ See Ackerman \& Katyal, supra note 6, for details.

${ }^{29}$ See id. (it is rich with detail).

${ }^{30}$ U.S. ConsT. art. IV.

${ }^{31}$ Ackerman, Transformations, supra note 6, at 99-185.

${ }^{32}$ Id. at 270 .
} 
limited work after a certain point. According to positivist jurisprudence, a constitutional order consists of legal rules whose validity can be traced to a constitution (written or unwritten), whose validity, in turn, is determined by an ultimate rule of recognition. ${ }^{33}$ But when we get to the rule of recognition, the chain of validity runs out. The rule of recognition can be neither valid nor invalid, because validity is a property of rules within a legal order that requires reference to a higher rule, which is not possible with respect to the rule of recognition itself. Although Kelsen argued that the validity of the rule of recognition (his Grundnorm) is presupposed, H. L. A. Hart rightly pointed out that validity is an internal statement about the relationship of rules within a legal system and the rule of recognition. The better view is that the rule of recognition merely exists, as a matter of sociological fact-defined by Hart as acceptance by the officials who govern themselves by it. ${ }^{34}$

As Frederick Schauer has explained, just as a constitution in its entirety can be displaced by a new constitution-which then becomes legally effective, regardless of the failure to comply with the formal legal rules for constitutional change of the previous constitutional order, since it has secured the requisite degree of official acceptance under a new rule of recognition-so, too, can partial modifications to the American Constitution become legally effective, notwithstanding the failure to comply with formalities for constitutional change spelled out by article $5 .{ }^{35}$ This is true either because the rule of recognition permitted amendment outside the formal legal order prior to those changes, or (more likely) because that rule was modified to accept such changes. Crucially, in the positivist view, such changes to the rule of recognition itself, albeit of legal consequence, are analytically distinct from and prior to law. They are conditioned by a range of political, moral, and other factors that are best described as nonlegal in character. In the American case, Ackerman's focus on the federal government suggests that the requisite degree of acceptance might entail the acquiescence by the principal institutions of the federal governmentCongress, the presidency, and the Supreme Court-for a range of nonlegal

\footnotetext{
${ }^{33}$ For a helpful explanation of how the constitution of a legal-political order is not its rule of recognition, see Joseph Raz, On the Authority and Interpretation of Constitutions: Some Preliminaries, in Constitutionalism: Philosophical Foundations 152, 160-162 (Larty Alexander ed.. Cambridge Univ. Press 1998).

${ }^{34}$ Herbert Luonet Adolphus (H.L.A.) Hart, The Concept of Law 105-107 (Oxford Univ. Press 1961). This perspective on the ultimate root or title of a constitutional order raises a host of interesting issues that we must bracket for the moment. These include whose acceptance and what kind of acceptance must be met for a rule of recognition to "exist." For a recent discussion. see Matthew D. Adler, Popular Constitutionalism and the Rule of Recognition: Whose Practices Ground U.S. Law?, 100 Nw. U. L. Rev. 719 (2006)

${ }^{35}$ Frederick Schauer, Amending the Presuppositions of a Constitution, in RESPONDING TO IMPRRFECTION: The Theory and Practice of Constttutional Amendment 145 (Sanford Levinson ed., Univ. Chicago Press 1995).
} 
reasons. In sum, although constitutions purport to be entirely selfvalidating and to regulate constitutional change through law, that is a rhetorical, not a legal, statement that misdescribes and obscures a political practice of acquiescence, not only for constitutions themselves but also for constitutional modifications that are functionally equivalent to formal amendments but do not comply with constitutional formalities. ${ }^{36}$

Whatever the merits of the argument from the standpoint of revolutionary legality, Ackerman rejects it. When considering a reading of article 5 that would make it the exclusive means of constitutional amendment, he asks " $[w]$ hy, then, read such a demand into the text at the cost of delegitimizing the Fourteenth Amendment?" ${ }^{37}$ Ackerman's worry appears to be that accepting the revolutionary and extralegal nature of the regime changes wrought by Reconstruction and the New Deal would somehow undermine the legitimacy of those changes. In other words, to Ackerman, legality is a sufficient criterion for legitimacy, such that constitutional change brought about without recourse to legal procedure would be illegitimate. To the extent that moments of gross illegality launched entire constitutional regimes, the regimes themselves would be illegitimate as well-creating what Ackerman terms "the problem of revolutionary legitimacy." 38

Ackerman resolves this problem by ascribing these seemingly extralegal changes to his system of so-called higher lawmaking_"a third way"39 that rejects the "dichotomy between legalistic perfection and lawless force," thereby showing that "law-breaking does not necessarily imply lawlessness"41 and, indeed, can produce viable constitutional "amendment." ${ }^{42}$ This parallel process exists alongside article 5 and is thus an alternative but equally effective mechanism for constitutional change.

What does higher lawmaking look like? Ackerman describes a highly stylized and complicated set of interactions involving both popular mobilization in favor of constitutional change and "institutional jujitsu"43 between the branches of the federal government. First, there is "signaling," whereby a movement "earns the constitutional authority to claim that ... its reform

\footnotetext{
${ }^{36}$ See also Frederick Schauer, Deliberating About Deliberation, 90 Mich. L. Rev. 1187 (1992) (reviewing ACKERMAN. Foundations, supra note 6). Cf. Kent Greenawalt, The Rule of Recognition and the Constitution, 85 Mrсн. L. Rev. 621 (1987).

37 ACKerman, TRansformations, supra note 6, at 16.

${ }^{38}$ ACKERMAN, Foundations, supra note 6 , at 171.

${ }^{39}$ ACKerman, Transformations, supra note 6 , at 33.

${ }^{40}$ Id. at 116 .

${ }^{41} I d$. at 14.

${ }^{42} I d$ at 270 .

${ }^{43}$ Id. at 13 .
} 
agenda should be placed at the center of sustained public scrutiny."44 This is followed by the "proposal," a phase during which the popular movement must translate its calls for change "into a series of more or less operational proposals for constitutional reform." 45 Next comes "mobilized deliberation," which comprises a series of substages: a "constitutional impasse" among different branches of the federal government, reflecting resistance by conservative branches of the government to the proposed constitutional changes; a "decisive electoral mandate" for the institutional proponents of revolutionary constitutional change; an "unconventional assault" by proponents on the conservative institutions; a "switch in time" by dissenting institutions to endorse the constitutional change; and a "consolidating election," in which the public ratifies this interinstitutional settlement. ${ }^{46}$ The final stage is "legal codification," when the Supreme Court translates the constitutional reform into constitutional doctrine. According to Ackerman, the requirements of this higher lawmaking system were met at the country's founding, the Reconstruction, and the New Deal, thus solving his dilemma by providing a legal basis of legitimation for each of these episodes.

\subsection{Higher lawmaking: Historical fact or legal fiction?}

Ackerman's model has attracted a large literature, most of it highly critical of both its descriptive accuracy and normative desirability. ${ }^{47} \mathrm{~A}$ central assertion of his descriptive claim is that the system of higher lawmaking was self-consciously

${ }^{44}$ ACKERMAN, Foundations, supra note 6, at 266.

${ }^{45} \mathrm{Id}$.

${ }^{46}$ ACKERman, TRAnsformations, supra note 6 , at 18-20.

${ }^{47}$ See, e.g., Sandalow, supra note 18; Schauer, supra note 36; Suzanna Sherry, The Ghost of Liberalism Past, 105 Harv. L. Rev. 918 (1992); Michael Klarman. Constitutional Fact/Constitutional Fiction: A Critique of Bruce Ackerman's Theory of Constitutional Moments, 44 STAN. L. Rev. 759 (1992); William W. Fisher III, The Defects of Dualism, 59 U. CHI. L. Rev. 955 (1992); Jonathan Simon, Columbus in the Twilight Zone: Bruce Ackerman's 'Discovery' of the Constitution. 17 L. \& Soc. INouri 501 (1992); Jennifer Nedelsky, The Puzzle and Demands of Modern Constitutionalism, 104 Eтнпсs 500 (1994); Kent Greenawalt, Dualism and Its Status, 104 ErHics 480 (1994); Don Herzog, Democratic Credentials, 104 ETHICs 467 (1994); James E. Fleming. We the Exceptional American People, 11 Const. Comment. 355 (1994); Michael W. McConnell, The Forgotten Constitutional Moment. 11 Const. CoMMENT. 115 (1994); Larry Kramer, What's a Constitution For Anyway? Of History and Theory. Bruce Ackerman and the New Deal, 46 CASE W. Res. L. Rev. 885 (1996): Frank Michelman, Constitutional Fidelity/Democratic Agency, 65 Fordham L. Rev. 1537 (1997); Lawrence Sager, The Betrayal of Judgment, 65 Fordham L. Rev. 1545 (1997); Mark Tushnet, Constituting We the People. 65 FordHAM L. Rev. 1557 (1997): Colin Gordon, Rethinking the New Deal, 98 Couvm. L. Rev. 2029 (1998); L.A. Powe. Jr., Ackermania or Uncomfortable Truths?, 15 Const. Comment. 547 (1998); Fleming, supra note 8; William E. Forbath, Caste, Class, and Equal Citizenship, 98 MicH. L. Rev. 1 (1999); Daniel J. Hulsebosch, Civics 2000: Process Constitutionalism at Yale, 97 Mich. L. Rev. 1520 (1999); Michael Gerhardt. Ackermania: The Quest for a Common Law of Higher Lawmaking. 40 WM. \& MARY L. Rev. 1731 (1999); Symposium, Moments of Change: Transformation in American Constitutionalism, 108 YALE L.J. 1917 (1999). 
understood as a process of constitutional amendment by citizens and various institutional actors during the three constitutional moments he identifies. In particular, Ackerman argues that the relevant actors in each episode ( $a$ ) were aware of the existence and particular features of a system of higher lawmaking outside the formal procedures for constitutional amendment; (b) purposely deployed this system in preference to proceeding through the textually prescribed procedures for constitutional amendment; $(c)$ interpreted the actions of other actors through the lens of this system; $(d)$ viewed earlier constitutional moments as instances of higher lawmaking and understood themselves as following those "precedents" by engaging in the same constitutional ritual; and (e) viewed any differences between their behavior and that of political actors in previous episodes as modifications or elaborations of the system and as departures from constitutional precedent.

These are strong claims, nonetheless, Ackerman is clear in making them. Consider a few examples. At the outset of his "revisionary narrative"48 in Foundations, Ackerman describes how, during the Reconstruction and the New Deal, political actors self-consciously worked within and developed the higher lawmaking process. According to Ackerman, the "sources ... reveal both Reconstruction Republicans and New Deal Democrats engaging in selfconscious acts of constitutional creation." 49 He continues, "[r]ather than meekly following the marching orders of the Federalists, both Republicans and Democrats were constitutionally creative procedurally no less than substantively - and they knew it." ${ }^{50}$ In defending the application of his higherlawmaking system to the adoption of the Thirteenth Amendment, Ackerman emphasizes the subjective understandings of the American people in deciding whether to support a constitutional proposal: "[w]hile this framework may seem overly formulaic ... the American people could hardly be said to exercise their popular sovereignty without a credible signal that reformers were seriously planning a constitutional transformation, without learning the outlines of the proposal, and so on." ${ }^{1}$

Ackerman makes his strongest empirical claims with respect to the New Deal. Thus, in describing the decision in Schechter Poultry Corporation v. United States, ${ }^{52}$ Ackerman says that the Court's "words ... challenged the President to run against the Court in the next election and seek to gain a mandate from the People in support of his corporatist initiative"; that the Court struck down the federal legislation because "[o]n its view, the Democrats assembling on Capitol

\footnotetext{
${ }^{48}$ Ackerman, Foundations, supra note 6 , at 44 .

${ }^{49}$ Id.

${ }^{50} I d$.

${ }^{51}$ ACKerman, Transformattons, supra note 6, at 124 (emphasis added).

52295 U.S. 495 (1935).
} 
Hill in 1933 had not earned the popular authority to displace the tradition of Congressionally centered government with a corporatist regime based on Presidential leadership"; and that "the Court put Americans on notice that the New Deal was shaking the foundations - -and it was not too late to withdraw their mandate." ${ }^{53}$ Summing up his analysis of the New Deal, Ackerman claims that ignoring the operation of the higher lawmaking system in that context would not be "doing justice to the protagonists' own understanding of the period." 54

Why does Ackerman make these empirical claims, and why does his entire argument depend on them? Imagine two different accounts of the way in which each of the constitutional moments Ackerman has identified actually unfolded. In the first, constitutional actors seeking to effect legal change simply saw themselves as acting outside the law. Their opponents may have accused them of acting illegally and may have insisted on the importance of proceeding through article 5, whether or not they agreed with the substance of the proposed constitutional change. However, for a number of possible reasons, the claims of legality were not decisive for constitutional reformers. They may have been indifferent to legal forms entirely, focusing instead on the substantive legitimacy of the proposed constitutional changes. Alternatively, they may have taken the claims of formal legality seriously but thought they were outweighed by the substantive legitimacy of their constitutional proposals, which may have been unachievable through strict adherence to constitutional process. It may be that they were operating within the framework of popular sovereignty, holding that the people retain the inherent power to set aside the constitutional structures they had given themselves at the founding.

The attempt to implement constitutional change outside article 5essentially a constitutional coup-would have produced interinstitutional struggles, if the constitutional reformers had gained an institutional beachhead. They might have used mechanisms available to them under existing constitutional arrangements-in the case of Congress, impeachment of the president, and changes to the membership, size, and jurisdiction of the Supreme Court-to exert pressure on dissenting institutions. Mass political mobilization, through elections, could have played a role in exerting political pressure.

\footnotetext{
${ }^{53}$ Ackerman, Transformations, supra note 6, at 295-296, 303 (emphasis added).

${ }^{54}$ Id. at 382. Finally, Ackerman argues that an awareness of the higher lawmaking system was evident during the attempt of Reagan Republicans to make transformative appointments to the Supreme Court (such as Robert Bork). In describing the (contemporaneous) attempt of the Reagan Republicans to engage in constitutional politics, he suggests that the higher lawmaking system "is now at the very center of the constitutional consciousness of the American People." ACKERMAN, Foundations, supra note 6, at 268. Looking back at the failed Bork appointment in Transformations, he reiterates that " $[w]$ hen citizens of the modern republic made their own efforts to gain higher lawmaking authority, it offered them an established language and process within which to proceed." Ackerman, Transformations, supra note 6 , at 389.
} 
The dissenting institutions may have acquiesced eventually for a range of reasons: because they changed their minds on the substantive legitimacy of the constitutional reform, because they amended their views on the importance of formal legality, or because they concluded that the personal and institutional costs of resistance outweighed any concerns regarding the substance of the proposals and legal process. Because of their acquiescence, the American Constitution changed, ultimately recognized in the courts-much in the manner that revolutionary constitutions have been recognized by courts across the world as being legally effective.

The second account, of course, is Ackerman's system of higher lawmaking. To be sure, these two accounts have important elements in common. Article 5 was not complied with in either. Moreover, the constitutional actors were fully aware of their noncompliance and deliberately chose to proceed without formal constitutional amendment. Notwithstanding the choice to proceed outside textually recognized channels, the goal of the constitutional actors was not to destroy the American constitutional system and precipitate a descent into lawlessness. Rather, their goal was to change the Constitution in a way that would have concrete legal consequences in courts of law after such a change had taken effect. Moreover, the externally observable patterns of political behavior are nearly identical, as is much of the political discourse employed by the parties.

However, despite these commonalities, the two accounts are fundamentally different in one respect. In the first, the political actors did not regard themselves as operating within a legally recognized mechanism of constitutional change, whereas in the latter they did. This is a critical distinction, because the latter attitude toward legally constituted processes is what defines the legal mind-set. As Hart famously explained, legal subjects have an "internal" attitude toward legal norms-what he termed the "internal point of view." The internal point of view captures the idea that actors within a legal order plan, structure, describe, explain, and justify their own actions through the lens of what they believe the law permits or requires, and they interpret, judge, and publicly react to the actions of other actors in light of the law as well. Laws are guides to conduct, reasons for behaving in certain ways and not behaving in others, standards against which to assess deviations from the law, and justifications for demands for law-compliant behavior and for criticism of nonconformity. As Hart also said, "officials, lawyers, or private persons ... use them, in one situation after another, as guides to the conduct of social life, as the basis for claims, demands, admissions, criticism, or punishment. ..." ${ }^{55}$ Constitutional actors engaging in a constitutional moment, accordingly, should understand whether certain conduct is part of a particular stage in the process of higher lawmaking-for example, "signalling" or an "unconventional assault"-and frame their responses according to the rules of this legal process.

${ }^{55}$ HART, supra note 34 , at 88 . 
If constitutional actors during constitutional moments did not regard the rules of higher lawmaking from an internal point of view, Ackerman would not be able to demonstrate that they were engaged in a legal procedure as opposed to an extralegal process that had the effect, and possibly the purpose, of producing legal change. Ackerman makes this empirical claim because it is crucial to his argument. ${ }^{56}$ How does Ackerman fare in supporting his claim with the evidence? It is in Transformations that he sets out a detailed historical discussion of each of his constitutional moments. It is, therefore, surprising that, at the end of Transformations, after having presented his historical evidence, he retreats from his descriptive claim. In his analysis of the transformative opinions of the New Deal, he states that he wants to move away from "the old and tired debate about the subjective motivations of the two justicesHughes and Roberts-who engineered the switch by forming a solid bloc with the three so-called liberals, Brandeis, Cardozo, and Stone. Unsurprisingly, the evidence on this matter is equivocal. But even if Roberts and Hughes had been apolitical legalists of legendary proportion, I could not care less. ..." Since Ackerman cannot make the argument that the subjective motivations of the justices do not count, this passage signals that something is amiss.

What is wrong, according toleadingstudents of thefounding, Reconstruction, and the New Deal, is that Ackerman largely fails to make his historical case. ${ }^{58}$ To be sure, Ackerman offers ample evidence of awareness among constitutional actors, especially during the founding and the Reconstruction, that constitutional change was being achieved illegally (although not all constitutional actors conceded this point). But this is not enough. Ackerman also needs to provide evidence that constitutional actors were aware that they were working the gears of an alternative system of constitutional change. ${ }^{59}$ Unfortunately, all the evidence shows is that the constitutional actors had engaged

\footnotetext{
${ }^{56}$ Ackerman's critics agree that his argument stands or falls on the historical case he makes for higher lawmaking. As Stephen Griffin puts it, "[w]ithout self-conscious understanding, Ackerman ... has an [sic] historical narrative that greatly deepens our understanding of how constitutional change has occurred through essentially political means. But he does not have evidence of a legal process." Stephen Griffin. Constitutional Theory Transformed, 108 Yale L.J. 2115, 2147 (1999).

${ }^{57}$ ACKERman, Transformations, supra note 6, at 343.

${ }^{58}$ See Jack N. Rakove, The Super-Legality of the Constitution, or, a Federalist Critique of Bruce Ackerman's Neo-Federalism. 108 YaLE L.J. 1931 (1999): Michael Les Benedict. Constitutional History and Constitutional Theory: Reflections on Ackerman, Reconstruction, and the Transformation of the American Constitution, 108 Y ALE L.J. 2011 (1999); Rogers Smith, Legitimating Reconstruction: The Limits of Legalism, 108 YALE L.J. 2039 (1999); William E. Leuchtenburg. When The People Spoke, What Did They Say? The Election of 1936 and the Ackerman Thesis, 108 Y ALE L.J. 2077 (1999); Griffin, supra note 56.

${ }^{59}$ Rogers Smith, for example, criticizes Ackerman because his "effort to vindicate the procedural legitimacy of Reconstruction within his terms leads him to slight the understandings of American constitutional institutions and processes that many of the relevant actors publicly advanced at the time." Smith, supra note 58, at 2056.
} 
self-consciously in a legal revolution they hoped would be accepted, in the end, by all constitutional actors as legally effective (as, for example, the American Revolution had been).

Consider one set of examples-the judicial acceptance of a non-article 5 amendment through a "consolidating judgment." Since courts must justify their decisions through reasoned opinions, we can expect to see an explicit acknowledgment of the higher lawmaking process. However, the evidence Ackerman offers is very weak. The first instance in which the U.S. Supreme Court interpreted the Fourteenth Amendment was in the Slaughterhouse Cases. ${ }^{60}$ Ackerman rightly notes that, although the Court was divided over the interpretation of the amendment, it was unanimous in accepting its validity. But this begs the question of the basis upon which the Court regarded the Fourteenth Amendment as valid. Ackerman rests his case on a single phrase in the majority judgment that refers to the Reconstruction amendments"within the last eight years three other articles of amendment of vast importance have been added by the voice of the people to that now venerable instrument." ${ }^{61}$ Ackerman claims that the passage is proof of judicial awareness of higher lawmaking, because the Court "speaks the unmediated language of popular sovereignty without trying to establish the amendments' legal pedigree under Article Five." ${ }^{12}$ Admittedly, the passage is consistent with that view. However, it is consistent with another view as well-that article 5 had been followed, and that the requisite degree of state and federal consent, through institutions accountable to the electorate, amounted to the adoption of the amendments by "the people" (even though such a view may be mistaken). And when we turn to the "consolidating" judgments of the New Deal, by Ackerman's own account those decisions contain no language capable of being interpreted as judicial acknowledgment of non-article 5 constitutional amendments. ${ }^{63}$ Indeed, Ackerman argues that the judgments deliberately created "an impression of substantial doctrinal continuity" that masked the "disequilibrium between revolutionary holdings and traditional dicta" ${ }^{44}$ and were followed up by judgments that did acknowledge the doctrinal revolution that had taken place. ${ }^{65}$ But, again, these later judgments do not refer to the higher lawmaking process.

\footnotetext{
${ }^{60} 83$ U.S. 36 (1873).

${ }^{61}$ Id. at 67.

${ }^{62}$ Ackerman. Transformations, supra note 6 , at 245.

${ }^{63}$ West Coast Hotel v. Parrish. 300 U.S. 379 (1937): NLRB v. Jones \& Laughlin Steel, 301 U.S. 58 (1937).

${ }^{64}$ Ackerman. Transformations, supra note 6, at 360.

${ }^{65}$ E.g.. United States v. Carolene Products, 304 U.S. 144 (1938); Erie Railroad Co. v. Tompkins, 304 U.S. 64 (1938).
} 
If we turn to the two cases that Ackerman discusses in which the Court has addressed the mechanisms of constitutional change directly-Coleman v. Miller (on article 5) ${ }^{66}$ and Casey v. Planned Parenthood (on overruling precedents in constitutional cases) ${ }^{67}$ - he fares no better. Although Coleman does discuss the coercion of state governments by the Reconstruction Congress to secure passage of the Fourteenth Amendment and goes on to state that " $[t]$ his decision by the political departments of the Government as to the validity of the adoption of the Fourteenth Amendment has been accepted," 68 this language may be read in a number of different ways. The process surrounding the ratification of the Fourteenth Amendment simply may be an example that supports the narrow proposition emerging from the case, which was raised by the facts--that under article 5 "the efficacy of ratifications by state legislatures, in the light of previous rejection or attempted withdrawal, should be regarded as a political question ... with the ultimate control in the Congress." ${ }^{.99}$ Or even if Coleman can be read as referring to constitutional change in contravention of article 5 , it does not follow that the judgment endorses higher lawmaking. The judgment can be read as no different from that of a common law court that accepts an unconstitutional regime change for a variety of strategic and pragmatic reasons that have nothing to do with popular sovereignty or adherence to an alternative process of constitutional amendment. Casey does not assist Ackerman either. The Casey plurality shows how the New Deal decisions, overruling Lochner-era jurisprudence, flow from a judicial assessment that the factual premises of laissez-faire constitutionalism were mistaken. ${ }^{70}$ Higher lawmaking does not enter into its analysis at all. Oddly enough, Ackerman does not even attempt to read Casey as endorsing his higher-lawmaking system, if only implicitly.

\subsection{Rescuing Ackerman: Reinterpreting constitutional moments as constitutional failures}

Where does this leave us? Although his historical argument for a higher-lawmaking system is unsuccessful, Ackerman makes a major contribution by placing illegal moments of regime change at the center of constitutional theory. This phenomenon raises a question that can be asked not just of the United States but of other jurisdictions as well. Why did political actors act outside of normal constitutional processes to effect constitutional change, given the availability of formal constitutional amendment?

\footnotetext{
66307 U.S. 433 (1939).

${ }^{67} 505$ U.S. 833 (1992).

${ }^{68} 307$ U.S. 433, 449-450 (1939).

${ }^{69} 307$ U.S. 433, 450 (1939).

${ }^{70} 505$ U.S. 833, 861-862 (1992).
} 
Those of Ackerman's critics who accept his argument that American constitutional history contains important moments of legal discontinuity do not address this question. ${ }^{71}$ Ackerman does not do much better. One of the most puzzling features of We the People is that Ackerman never provides a sustained explanation of why American political institutions implemented dramatic constitutional changes in a manner that bypassed the process of formal constitutional amendment. However, if we read Ackerman carefully with this question in mind, we see that he offers answers, although they are not always clear. The closest he comes to a direct reference is when he suggests that during Reconstruction and the New Deal, America faced a "crisis" whose solution was impeded by article 5 :

At two of the greatest crises in their history, Americans faced the very grave risk of a false negative. If they chose to play punctiliously by the rules of Article Five, Reconstruction Republicans and New Deal Democrats confronted the clear and present danger that their long and successful struggle to mobilize the People for fundamental change would be legalistic nit-picking. ${ }^{72}$

The key to Ackerman's argument is the existence of a crisis. Thus, to make his argument successfully, he needs to offer a definition of the kind of crisis that America faced and to tell us why article 5 was thought incapable of addressing it. Here is what he says about Reconstruction:

Without this kind of unconventional creativity, it is hard to see how Americans could have democratically transformed themselves from a decentralized Union of white men to a Nation of all races and creeds whose government-on both federal and state levels-is actively engaged in assuring a better life for all citizens. ${ }^{73}$

So Ackerman's answer may be as follows. Prior to Reconstruction, the people of the United States defined themselves as a nation of white citizens whose membership in the American political community derived from their political status as citizens of the states, and who expressed their consent to constitutional change through state legislatures. The substantive constitutional changes wrought by the Reconstruction amendments marked a fundamental challenge to that premise. But since the rules of article 5 also reflected this original conception of political community, the disagreement occasioned by the Reconstruction amendments operated on two levels. There was a disagreement on constitutional substance-that is, over racial equality and the federal government's power to protect it. Moreover, there was a disagreement on

\footnotetext{
${ }^{71}$ E.g., Smith, supra note 58; and Rakove, supra note 58.

${ }^{72}$ Ackerman, Transformations, supra note 6, at 29.

${ }^{73}$ Id. at 389.
} 
constitutional process, because the existing rules governing constitutional amendment reflected one of the competing, substantive conceptions of American political community on the table that the Reconstruction amendments sought to displace.

Ackerman carries these themes forward in his Holmes Lectures, ${ }^{74}$ which offer the most recent statement of this theory. It is here that, at last, he squarely poses and answers the question of why constitutional actors stepped outside the formal procedures for constitutional amendment. His answer is that "[w]e have become a nation-centered People stuck with a state-centered system of formal constitutional amendment," creating "an increasing mismatch between the federalist framework of formal amendment and the rising national consciousness of the American people."75 In other words, article 5 embodies a vision of political community in which the constituent actors are state legislatures or conventions. Reconstruction, by contrast, according to Ackerman, created a "new nation-centered understanding of American citizenship," which "required a nation-centered system of constitutional revision" that stands in stark contrast to the political theory embodied in article $5 .{ }^{76}$

Understood this way, the crisis of Reconstruction involved a serious and profound constitutional breakdown, but of a particular sort. A basic ambition of constitutionalism is to channel political conflict, which might otherwise spill into the streets, into institutions that operate peacefully, according to law, and that reach decisions that members of a political community accept as authoritative. To function properly, constitutionally created institutions must operate according to rules of procedure that specify how decisions are made. For institutional decisions to produce political settlement, those institutions and their decision-making procedures must be viewed by political actors as standing outside the arena of politics, as constituting and regulating political life while not forming part of it-as neutral among the competing political positions on the table. If the mechanisms by which political disagreement is managed were themselves subject to ongoing political contestation, it would be difficult for institutional settlement to translate into political settlement. Particular decisions could always be challenged by shifting the political battlefield to a higher level and arguing that the decision was illegitimate because the procedure by which it was arrived at was itself the proper subject of politics.

The procedures for constitutional amendment, and their relationship to constitutional politics, can be conceptualized in an analogous way. In addition to creating the procedural framework for normal politics, constitutions also create the procedural framework for constitutional politics. For the rules of constitutional amendment to operate effectively, they must also be accepted as

\footnotetext{
${ }^{74}$ Ackerman, Holmes Lectures, supra note 6.

${ }^{75}$ Id. at $1743 \& 1761$.

${ }^{76}$ Id. at 1748 .
} 
standing outside the terrain of substantive constitutional politics, as constituting and regulating constitutional politics while not forming part of it, and as neutral among the competing constitutional positions in play.

The problem with this highly simplified picture is that constitutionally created procedures - both for normal and constitutional politics-are far from substantively neutral themselves. Rather, as Jeremy Waldron has argued, political procedures reflect competing conceptions of the very sorts of values that are the bread and butter of both normal and constitutional politics. ${ }^{77}$ In particular, by determining which individuals and communities can participate in political decision making, and what role those individuals and communities play, decision rules reflect controversial judgments about the locus of political sovereignty and the very identity of a political community. For example, debates over who has the right to vote, what decisions are subject to voting, and according to what rules reflect basic questions regarding the character of a political community. So the boundary between substantive political disputes and the procedural frameworks within which those disputes play out is highly artificial. Liberal democratic constitutionalism depends, then, on the suspension of political judgment with respect to institutions and institutional decisionmaking procedures in order to purchase the prospect of political settlement. The entrenchment of decision-making procedures in many constitutions should accordingly be understood as one strategy for facilitating the suspension of political judgment. By increasing the transaction costs of changing those procedures, constitutional entrenchment renders debates aimed at changing them less attractive.

The suspension of political judgment with respect to political procedures will become most difficult to sustain at moments when the substantive dispute challenges the conception of political community that underlies the procedural framework within which that debate occurs. Call these moments of constitutive politics. With respect to the rules of normal politics, the result will be to shift the terrain of disagreement up one level, from normal politics to constitutional politics, which, in turn, is regulated by the rules governing constitutional amendment. However, if it becomes impossible to suspend political judgment regarding the procedures for constitutional amendment-that is, at moments of constitutive constitutional politics - there is no higher level to which the dispute can be shifted. Even if one designed a constitution to create a special set of rules to regulate amendments to the rules for constitutional amendment, the same problem might arise with respect to those rules. It is impossible to continue this strategy ad infinitum. In the absence of agreed-to procedures for constitutional decision making, institutional settlement cannot yield political settlement. The result may be that the constitutional system itself may collapse.

${ }^{77}$ Jeremy Waldron, Judicial Review and the Conditions of Democracy, 6 J. PoL. Pнп. 335 (1998). 
On this reading, Ackerman may believe that the Reconstruction was such a case. Ackerman tells a similar story about the founding-namely, that the Articles of Confederation reflected a conception of political community that the Federalist Constitution directly challenged:

Begin with the basic problem that led the Federalists to their revolutionary break with the rules. The Federalists were the first, but not the last, to assert that the pre-existing system gave the states too much power to veto constitutional initiatives emerging from the center. While it is a mistake to view them as embracing the more emphatic nationalisms of Reconstruction Republicans or New Deal Democrats, Federalists were espousing a vision of the Union that was relatively nationalistic for its time and place-nationalistic enough to make it impossible to enact through a system that gave so much power to the states. ${ }^{78}$

It may very well be that two of Ackerman's constitutional moments are, in truth, moments of constitutional paralysis and failure, resulting from the inability of the rules governing constitutional amendment to constitute and regulate moments of constitutive constitutional politics because those rules embodied one of the conceptions of political community on the table. This description, of course, is quite different from Ackerman's characterization of constitutional moments as high constitutional politics marked by closely focused and public-minded mass political deliberation.

\section{Do constitutional moments travel? The Secession Reference}

\subsection{Constitutional moments reinterpreted: A comparative example}

Ackerman's constitutional moment, thus reinterpreted, consists of an extralegal constitutional change, resorted to because of a failure of the formal rules of constitutional amendment. This understanding of constitutional moments can help to make sense of what is simultaneously one of the most controversial, important, and puzzling constitutional episodes in recent Canadian constitutional history-the judgment of the Supreme Court of Canada in the Secession Reference. Although the Court purported to do otherwise, it amended the Canadian Constitution under the guise of constitutional interpretation. Moreover, since the relevant rules confer the power of constitutional amendment only on the political institutions, the Court acted extralegally. But since the procedures for constitutional amendment themselves reflected a substantive conception of the Canadian political community that was challenged by the Quebec secession movement, these procedures were drawn into constitutional politics and proved incapable of legally regulating the process of

\footnotetext{
${ }^{78}$ Ackerman \& Katyal, supra note 6. at 569-570 (emphasis added).
} 
secession, including the adoption of procedures that would be acceptable to all parties. The Court's judgment, therefore, must be understood against the backdrop of constitutional failure-as an extralegal move that the Court felt was made necessary by the breakdown of the procedures governing constitutional amendment.

\subsection{The Secession Reference as extralegal constitutional change}

The Supreme Court of Canada possesses an advisory jurisdiction and, in September 1996, the federal government posed three questions to the Court asking it to address aspects of the legal framework governing the secession of a province from the Canadian federation. The first of these questions asked if "[u]nder the Constitution of Canada ... the National Assembly, legislature or government of Quebec [could] effect the secession of Quebec from Canada unilaterally," that is, without the consent of other Canadian governments. The provisions of the Canadian Constitution governing provincial authority neither explicitly nor through interpretation provide for such a right. ${ }^{79}$ Moreover, since the Canadian Constitution creates the province of Quebec, defines its territory and borders, creates its legislative and executive branches, and confers limited areas of jurisdiction on them, Quebec is a creature of the Canadian Constitution, as opposed to a sovereign entity that preexisted, surviving the creation of the Canadian federation and retaining inherent sovereignty. ${ }^{80}$ The Canadian Constitution also creates federal institutions and confers limited authority on them that extends to the entire country, including Quebec. ${ }^{81}$ Finally, the Constitution asserts its supremacy over both the federal and provincial governments. ${ }^{82}$ The secession of Quebec would accordingly require a number of sweeping constitutional amendments that would authorize Quebec's governing institutions to effect the secession of the province and declare statehood, to transfer areas of existing federal jurisdiction to the province, and to terminate the legal authority of federal institutions over Quebec.

The debate over the right to unilateral secession, therefore, quickly turns into a problem of constitutional amendment. The rules for constitutional amendment consist of five different "amending formulas," which apply to different categories of amendments. ${ }^{83}$ All the amending formulas, save one, require the consent of the federal government. ${ }^{84}$ The one amending formula

${ }^{79}$ Constitution Act, $1867,30 \& 31$ Vict. Ch. 3 (U.K.), as reprinted in R.S.C., No. 5 (1985), §§ 58-68, 92, 92A, 93, 94A \& 94 [hereinafter Constitution Act, 1867].

${ }^{80} I d . \S \S 5,6,58-63,65-68,71-80,82-87$.

${ }^{81}$ Id. $\S 3,4,9-57,91,92(10), 92 A(2), 94,94 A, 95,96-101$.

${ }^{82}$ Constitution Act, 1982, being Schedule B to the Canada Act 1982, ch. 11 (U.K.), $\S 52$ [hereinafter Constitution Act, 1982].

${ }^{83} \mathrm{Id} . \S \S 38-47$.

${ }^{84} I d . \S 45$. 
that would permit a province to amend the Constitution unilaterally applies to "the constitution of a province," a term whose core meaning includes matters internal to a province and its institutions. ${ }^{85}$ The prevailing view is that this provision does not extend to the structure and powers of federal institutions or to the scope of provincial powers, changes to which would be required to effect the secession of a province. So the answer to question one is "no"-under the Constitution of Canada, a province cannot secede unilaterally.

But the judgment of the Supreme Court of Canada was dramatically different. The Court opened its consideration by signaling the importance of "underlying principles" and stated that it was "not possible to answer the questions" put to it without considering these principles. ${ }^{86}$ The Court identified the principles involved on the basis of a lengthy review of the "historical context,"87 which consisted of a selective account of the constitutional practice of Canadian governments since the founding of Canada in 1867. According to the Court, four principles characterize "the evolution of our constitutional arrangements": federalism, democracy, constitutionalism and the rule of law, and respect for minorities. ${ }^{88}$ The Court then applied these principles in developing a constitutional framework for secession in the context of a referendum vote that was "a clear expression by the people of Quebec of their will to secede from Canada."89 The Court clarified that a "clear" result must have two dimensions to it-that it "be free of ambiguity both in terms of the question asked and in terms of the support it achieves"90 - in other words, with respect to the wording of the question and the degree of public support required for that question. The Court provided further detail on both dimensions. The question had to be "a clear question in favour of secession."91 The level of support required was "a clear majority of Quebecers." "92 Taken together, this requirement has come to be known by the phrase "a clear majority on a clear question." 93

\footnotetext{
${ }^{85} \mathrm{Id}$.

${ }^{86}$ Reference re Secession of Quebec. [1998] 2 S.C.R. 217 , at para. 1.

${ }^{87}$ Id. at para. 32.

${ }^{88} I d$. at para. 48 .

${ }^{89} \mathrm{Id}$. at para. 87. The Court also referred to a "clear repudiation of the existing constitutional order and the clear expression of the desire to pursue secession by the population of a province," or "clear repudiation by the people of Quebec of the existing constitutional order." Id. at para. 88.

${ }^{90} \mathrm{Id}$. at para. 87.

${ }^{91}$ Id. at para. 148. In another formulation, the Court stated that the question was one which asked Quebecers to indicate "that they no longer wish to remain in Canada." Id. at para. 151.

92 The Court also used other formulations: "the unambiguous expression of a clear majority of Quebecers." Id. at para. 104. See also id. at para. 150: "a clear majority vote in Quebec."

${ }^{93}$ Id. at para. 153. What constitutes a "clear majority" and a "clear question" has generated extensive commentary in the literature; I will not address it here.
} 
The Court noted that the Constitution was silent on referenda, and that "a referendum, in itself and without more, has no direct legal effect, and could not in itself bring about unilateral secession." 94 But the Court then went on to state that a referendum vote that met these criteria "would give rise to a reciprocal obligation on all parties to Confederation to negotiate constitutional changes to respond to that desire." 95 This is the so-called "duty to negotiate," which flows from the four constitutional principles, which the Court deployed in order to reject "two absolutist propositions." 96 First, it rejected the view "that there would be a legal obligation on the other provinces and federal government to accede to the secession of a province, subject only to the logistical details of secession";"97 in other words, that "Quebec could ... invoke a right of selfdetermination such as to dictate the terms of proposed secession to the other parties." 98 But it also rejected "the reverse proposition, that a clear expression of self-determination by the people of Quebec would impose no obligations upon the other provinces or the federal government." 99 Rather, the Court reasoned that "other parties cannot exercise their rights in such a way as to amount to an absolute denial of Quebec's rights, and similarly, that so long as Quebec exercises its rights while respecting the rights of others, it may propose secession and seek to achieve it through negotiation." 100

The Court also addressed the issue of who the participants in such negotiations would be and how the negotiations must be conducted. The Court made many statements concerning the parties, involving Quebec and shifting combinations of other parties - the federal government, the provinces, and other participants. ${ }^{101}$ The Court said that the negotiations must be conducted "in accordance with the underlying constitutional principles already discussed,"102 which seemed to have two implications. First, it implied a procedural duty on

\footnotetext{
${ }^{94} \mathrm{Id}$. at para. 87.

${ }^{95} \mathrm{Id}$. at para. 88.

${ }^{96} I d$ at para. 90.

${ }^{97} \mathrm{Id}$.

${ }^{98}$ Id at para. 91.

${ }^{99} \mathrm{Id}$. at para. 92.

${ }^{100}$ Id. at para. 93.
}

${ }^{101}$ (a) "the other provinces and the federal government" (id. at paras. 88, 151; also see id. at paras. 92, 103); (b) Quebec, the federal government, the other provinces, and "other participants"; id. at para. 92; (c) Quebec and the other provincial governments, but perhaps not the federal government; (d) bilateral negotiations involving "the representatives of two legitimate majorities, namely the clear majority of the population of Quebec, and the clear majority of Canada as a whole, whatever that may be"-perhaps meaning the federal government, or potentially a joint federalprovincial negotiating team. (Id. at para. 93; also see id. at para. 152).

${ }^{102}$ Id. at para. 88. 
negotiators to take into account the four constitutional principles, ${ }^{103}$ such that negotiations would be "principled." 104 Second, it implied that the constitutional principles impose substantive restraints on the terms of whatever agreement is negotiated, when it said that " $[t]$ he negotiation process ... would require the reconciliation of various rights and obligations."105

The judgment was enormously surprising. It bore no relation to the submissions of the parties and intervenors or to the questions of the judges in the oral hearing. In addition, the judgment departed from the standard manner in which Canadian courts approach questions of constitutional interpretation. In Canadian constitutional practice, the starting point of constitutional interpretation is the text of the Constitution, although principles of substantive political morality-such as the constitutional principles identified and applied by the Court—play a role. As Frederick Schauer has persuasively argued, some constitutional provisions appear to incorporate principles of political morality "by reference" and, therefore, invite (but do not compel) courts to engage in the type of normative reasoning characteristic of moral and political philosophy. ${ }^{106}$ But not all constitutional provisions are worded in this way. Some provisions are relatively specific and precise and have interpretive frames narrow enough to create a strong presumption against the recourse to normative reasoning. In the end, constitutional text plays a primary role in signaling interpretive style. ${ }^{107}$

Indeed, the Court, in the Secession Reference itself, offered just such an account of the relationship of the constitutional text to the "underlying principles" of the Canadian Constitution, suggesting that the foregoing account reflected its standard approach to constitutional interpretation. The Court said that the "principles inform and sustain the constitutional text: they are the vital unstated assumptions upon which the text is based."108 That is, the constitutional text implements or actualizes underlying principles that are abstract and general. Moreover, this conception of the relation between principles and text suggests that the former could be used to interpret the latter, and to reconcile divergent or conflicting constitutional provisions. ${ }^{109}$ But the Court also

\footnotetext{
${ }^{103}$ Id. at para. 90. Thus, the Court said, "[t]he negotiation process must be conducted with an eye to the constitutional principles." Id. at para. 94.

${ }^{104}$ Id. at 104.

${ }^{105}$ Id. at para. 93; see also id. at paras. 101, 153. The "reconciliation" of principles connotes that principles cannot override one another. As the Court said earlier in its reasons: "These defining principles function in symbiosis. No single principle can be defined in isolation from the others, nor does any one principle trump or exclude the operation of any other." Id. at para. 49.

${ }^{106}$ Frederick Schauer, Constitutional Invocations, 47 FordHAM L. Rev. 1295 (1997).

${ }^{107}$ Frederick Schauer, Easy Cases, 58 S. CAL. L. Rev. 399 (1985).

${ }^{108}$ Reference re Secession of Quebec, [1998] 2 S.C.R. 217 at para. 49.

${ }^{109}$ Id. at para. 52.
} 
cautioned that the recognition of underlying principles "could not be taken as an invitation to dispense with the written text of the Constitution." 110 In other words, the text delimits constitutional interpretation, and principles on their own have no binding legal force.

Can we make sense of the judgment's reliance on unwritten constitutional principles to the extent that their application to the construction of a constitutional text permits or invites such an interpretive approach? Given the absence of a provision on secession, and the Court's statement that secession could be achieved through constitutional amendment, ${ }^{111}$ we should examine the procedures for constitutional amendment. But these do not provide a textual hook for the Court's judgment. Consider, for example, the rule that the vote of a clear majority in favor of a clear question on secession in a referendum would trigger negotiations. In Canada, the initiating process for constitutional amendment is the passage of a resolution by a provincial legislative assembly or Parliament. ${ }^{112}$ Although provinces and the federal government may opt to rely on referenda as part of the process of constitutional amendment, a referendum in itself is of no constitutional significance in initiating the amendment process.

The Court acknowledged the weak connection between constitutional principles and the constitutional text and offered an alternative account of its role in constitutional interpretation. It stated that principles themselves "in certain circumstances give rise to substantive legal obligations ... which constitute substantive limitations upon government action"; these obligations could be either "very abstract or general" or "more specific and precise," to fill "gaps in the express terms of the constitutional text."113 Thus, what must be recognized-and what the Court came close to saying itself-is that the Court wrote a novel "secession clause" into the Canadian Constitution through the use of unwritten constitutional principles. However, the major problem with gap filling through judicial interpretation is that the Canadian Constitution has already set up a process for filling constitutional gaps, whether perceived or actual-the process of constitutional amendment. The challenge for the Court in the Secession Reference was to justify why it did not permit the political actors to effect an amendment to the Constitution and, instead, engaged in amendment-like interpretation.

\subsection{The constitutional failure of the Canadian amending formulas}

The Supreme Court of Canada behaved in this fashion because of the failure of the processes of constitutional amendment spelled out in the Canadian

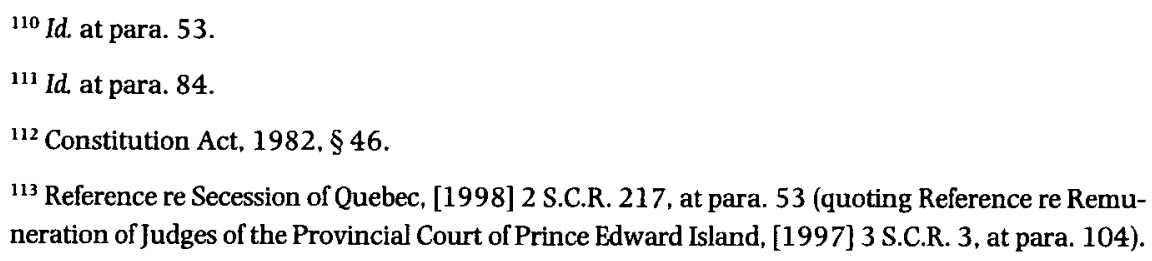


Constitution. This explanation is analogous to the situation during Reconstruction, when the rules in article 5 were unable to regulate constitutional politics precisely because they reflected a conception of the American political community that was itself challenged by the Reconstruction amendments; hence, they were unable to regulate constitutional change. A parallel dynamic took place in Canada in the mid-1990s. The applicable rules of constitutional amendment embodied the very conception of Canada that Quebec secessionists sought to challenge. For that reason, those rules failed in performing their basic function - to stand outside of constitutional politics, regulating and constituting that potential constitutional change-but, instead, were drawn into it.

An important theme in Canadian constitutional history has been the search for a procedure to amend the Canadian Constitution. This search was driven by the absence of an amending procedure in 1867 Constitution, ${ }^{114}$ which, as an ordinary British statute, left the power of amendment by default with the imperial Parliament. Accordingly, the development of an amending procedure was required in order to bring the Canadian Constitution "home" from Britain-a project of constitutional "patriation," a term popularized by Pierre Trudeau. ${ }^{115}$ For as long as the formal practical power of constitutional amendment rested outside of Canada, Canadian sovereignty was regarded as incomplete. Until the end of the First World War, this did not pose a great problem, as Canada understood itself as possessing internal powers of self-government, with international relations handled by Britain. What thrust the issue onto Canada's political agenda was the Balfour Declaration of 1926, which formally recognized Canada's statehood. ${ }^{116}$ The end of Canada's colonial status required that Canadian governments come to some agreement on the shape of a domestic amending procedure. However, an agreement did not occur until 1981and even then, it was not unanimous. ${ }^{117}$

Because of the curious constitutional dynamic created by Canada's incomplete Constitution and the country's gradual evolution to statehood, Canadian constitutional politics were driven by the search for a domestic amending formula for over fifty years. This proved to be enormously difficult.

\footnotetext{
${ }^{114}$ Constitution Act, 1867.

115 Roy Romanow, John Whyte \& Howard Leeson, Canada ... Notwithstanding: The Making of the Constitution, 1976-1982 (Carswell/Methuen 1984).

${ }^{116}$ The Balfour Declaration stated that Canada and Britain were "equal in status, in no way subordinate one to another in any aspect of their domestic or external affairs." SESSIONAL PAPERS. 1926, [Cmd.] 2768.

${ }^{117}$ In the interim, the power of constitutional amendment rested with Britain. Even in the Statute of Westminster enacted in 1931, whereby the imperial Parliament formally "terminated" its power to legislate for Canada and thereby recognized Canada's political independence, an exception was made for amendments to the Canadian Constitution. Statute of Westminster, 1931, 22, 23 Geo. 5. c. 4 (U.K.).
} 
In order to shift ultimate sovereignty back to Canada, Canadian political actors had to agree on where the locus of sovereignty should lie or, more accurately, who the constituent actors in a domestic amending procedure should be - the federal government, provincial governments, the national population, or various provincial populations. Answering this question, in turn, required political actors to grapple with the nature of the Canadian political community. On that basic question, there was a lack of consensus. The constitutional politics of constitutional amendment accordingly took place on two levels. It was concerned with practical questions of constitutional design. Yet it was also a symbolic politics, a terrain in which a struggle over the meaning of the country could occur. As a result, Canada's failure to secure agreement on a procedure to amend its Constitution can be understood, as Peter Russell has argued, as a consequence of the conflicting national narratives illustrating how Canadians had not yet constituted themselves as a sovereign people. ${ }^{118}$

The inextricable linkages between the constitutional politics of process and substantive constitutional politics serve as a backdrop against which to understand the failure of the rules to regulate the constitutional politics of secession in the mid-1990s. Quebec was a central player in the constitutional politics of constitutional amendment and consistently pressed for a constitutional veto, a stance informed by a vision of the Canadian political community and its place in it. But as Peter Oliver has explained, Quebec's self-understanding changed over time. ${ }^{119}$ Initially, Quebec invoked the "compact theory" of confederation, which imagined the Canadian Constitution as an agreement among the original federating colonies. On this view, the Constitution could be changed only with the parties' consent, which translated into vetoes for every province, including Quebec. Quebec eventually shifted away from the compact theory, because the vetoes threatened to thwart Quebec's own evolving constitutional agenda, which shifted focus in the 1960s from defending its constitutional position against erosion to expanding its areas of jurisdiction. Instead, Quebec formulated the "two nations" theory of Canadian federalism, which views Canada as a contract or treaty between two founding peoples, English and French, whose consent is required for constitutional changes. Quebec was the sole representative of French Canadians, which granted it a veto. By contrast, since the other provinces collectively spoke for English Canadians, no other province possessed a veto.

\footnotetext{
118 Peter H. Russell, Constitutional Odyssey: Can Canadians Become a Sovereign People? (2d ed., Univ. Toronto Press 1993).

119 Peter Oliver, Canada, Quebec, and Constitutional Amendment, 49 U. Toronto L.J. 519 (1999). See also Peter Oluver, The Constitution of Independence: The Deveiopment of Constitutional Theory in Australia, Canada, and New Zealand (Oxford Univ. Press 2005).
} 
It is against this background that the procedures governing constitutional amendment were adopted. ${ }^{120}$ The amending procedures do not give Quebec a veto of the scope it had sought as part of the two-nations theory of Canada. Rather than granting only Quebec a veto, they grant every province a veto and only with respect to a narrow set of constitutional issues that historically have been of interest to Quebec, such as "the composition of the Supreme Court of Canada."121 The amending procedures were part of a package of constitutional amendments agreed to by the federal government and the provinces other than Quebec in November 1981; they came into force in 1982. In addition to objecting to the substance of the package, Quebec quickly raised concerns regarding the manner in which it had been adopted; in so doing, the province relied on a convention of the existing Constitution that stipulated the federal government would not transmit requests to Britain to amend the Canadian Constitution without a "substantial" degree of provincial consent. ${ }^{122}$ Quebec argued that this convention, requiring a substantial degree of provincial consent, actually entailed unanimous provincial consent, on the basis of the compact theory. Later in the process, the province argued that there was an additional constitutional convention granting Quebec a veto, based on the two-nations theory. ${ }^{123}$ Quebec made these arguments to the federal government, which rejected them, and, after that, to the British government, which declined to intervene. It then turned to the courts, which rejected the existence of these conventions. Quebec viewed both the federal government's conduct and the Court's judgment as unconstitutional, setting the stage for it to argue that it was not bound by the rules governing constitutional amendment. Furthermore, the amending procedures that were adopted entrenched a substantive vision of Canada that was incompatible with Quebec's sense of its place in the Canadian federation.

This history illustrates that the procedures for constitutional amendment were perceived in Quebec as in no way neutral. The rules had become part of constitutional politics; they would not be able to perform their regulative function of constraining and channeling constitutional politics, especially in those instances where the decision rules were perceived as openly favoring one side in constitutional debate. To be sure, this would not be true, necessarily, of every constitutional amendment, because not every question of constitutional politics raises such existential issues. However, were such issues to arise, one would expect political actors to set those procedures to one side.

\footnotetext{
${ }^{120}$ Sujit Choudhry \& Jean-François Gaudreault-DesBiens, Frank Iacobucci as Constitution-Maker: From the Quebec Veto Reference to the Meech Lake Accord and the Quebec Secession Reference. 57 U. Toronto L.J. 165 (2007).

${ }^{121}$ Constitution Act, $1982, \S 41$.

${ }^{122}$ Reference re Resolution to Amend the Constitution, [1981] 1 S.C.R. 753.

${ }^{123}$ See, generally, Documents Relating to the Constitution Act, 1982, 30 McGuL L.J. 645 (1984/85).
} 
This is precisely what happened with respect to the constitutional politics of secession during the period from 1994 to 1998. The substantive question was whether Quebec should remain part of Canada or become an independent state. A central issue was the process whereby Quebec intended to determine its constitutional status. Quebec had enacted referendum legislation that clearly contemplated referenda that would be strictly consultative and nonbinding. ${ }^{124}$ A positive referendum vote in favor of sovereignty would not purport to effect a change in Quebec's constitutional status. However, the referendum question asked Quebecers whether "Quebec should become sovereign, after having made a formal offer to Canada for a new economic and political Partnership, within the scope of the Bill respecting the future of Quebec... ?"125 The bill referred to is Bill 1, An Act Respecting the Future of Québec. ${ }^{126}$ The key provision is section 1, which would have authorized the National Assembly "to proclaim the sovereignty of Québec" within a year of the referendum vote. Section 2 said that upon the proclamation of sovereignty, "Québec shall become a sovereign country," and it spelled out the well-established incidents of sovereignty belonging to an independent Quebec - "the exclusive power to pass all its laws, levy all its taxes and conclude all its treaties." The text of the declaration of sovereignty was set out in the preamble and concluded with the words "Québec is a sovereign country." Sovereignty meant Quebec's departure from the Canadian federation.

In short, Bill 1 made no pretense of proceeding by way of the Constitution; it contemplated, instead, that Quebec would become independent through what amounted to a legal revolution after issuing a unilateral declaration of independence (UDI) on the basis of a positive referendum vote. The constitutional implications of Bill 1 became clear in legal proceedings before the 1995 Quebec referendum, in which it was alleged that Quebec had set in motion a process to achieve Quebec's secession without relying on the authorized procedures for constitutional amendment. ${ }^{127}$ Quebec filed a motion to dismiss, which responded directly to this constitutional argument by asserting that "the will of people is the foundation of the authority of public power." 128 The constitutional theory at work, here, is the one described earlier, which holds that the rule of

\footnotetext{
${ }^{124}$ An act respecting the process for determining the political and constitutional future of Québec, S.Q. 1991 , ch. 34 .

${ }^{125}$ Motion Introducing the Referendum Question, presented by Premier Jacques Parizeau to the National Assembly of Quebec, Sept. 7. 1995.

${ }^{126}$ Bill 1, An Act Respecting the Future of Québec, 1st Sess., 35th Leg., Quebec, 1995.

127 The case was a constitutional challenge to the precursor of Bill 1: Draft Bill, An Act Respecting the Sovereignty of Quebec, 1st Sess., 35th Leg., Quebec, 1994.

${ }^{128}$ Motion of Attorney General of Quebec to Dismiss Mr. Bertrand's Motion for Interlocutory Measures, Bertrand v. Bégin, Aug. 24, 1995, Québec 200-05-002117-955 (Sup. Ct.) (author's translation).
} 
recognition of a constitutional order is a sociological fact that is neither valid nor invalid but simply exists, regardless of how this basic political fact arose-through legal mechanisms or a revolution, be it violent or velvet in nature. Accordingly, the Quebec government and many of the Quebec eliteincluding federalists committed to Quebec's remaining within Canadaviewed Quebec's accession to independence, and the termination of the sovereignty of the Canadian state over Quebec, as originating in the democratic will of Quebecers as expressed in a favorable referendum vote and followed by a declaration of sovereignty. This was considered an expression of political will that would operate to change the locus of sovereignty, and to which the law would have to adapt.

The Quebec Superior Court denied the motion to dismiss the constitutional challenge, stating that " $\mathrm{t}]$ he menace that the government of Quebec would pose to the political institutions of the Canadian federation is a serious question, which is by its nature justiciable with respect to the Constitution of Canada." 129 In response, Quebec took the unprecedented step of withdrawing from the proceedings. ${ }^{130}$ The message sent by Quebec was direct and clear-it refused to accept the authority of the Canadian courts and of the Canadian Constitution over its potential independence. The Supreme Court ruled, ultimately, that the actions undertaken by the Quebec government would lead Quebec to issue a universal declaration of independence (UDI) without first securing a constitutional amendment, and that this "would result in a break in continuity in the legal order, which is manifestly contrary to the Constitution of Canada." 131 The attorney general of Quebec stated in a press conference in response to the Court's ruling that a UDI would not and need not conform with the Canadian Constitution, because "the effect of a yes vote would be a rupture with the Canadian constitution ... Quebec will have become a nation."132

Quebec did not state explicitly why it refused to work within the framework of the Canadian Constitution. However, the answer becomes clear once we identify the substantive conception of Canada that is embodied in the procedures governing constitutional amendments and Quebec's place within that conception. Those procedures imagine Quebec as a constituent component of the Canadian federation, as a subnational political community with extensive but limited rights of self-government within Canada. The province is a constitutionally recognized actor in the process of constitutional amendment with the power to consent to constitutional amendments; however, its consent is

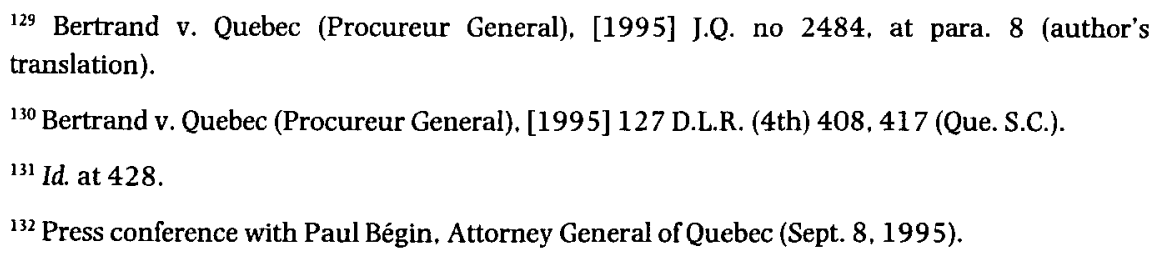


not absolutely required in all circumstances. This vision was at odds with both the two-nations and compact theories of Canada, each of which granted Quebec a veto over constitutional change.

Moreover, after 1982, in Quebec, the right to self-determination became a corollary of a constitutional veto over modifications to the Canadian federation, including the right for Quebec freely to determine its political and legal status. Although the right to secede does not follow necessarily from the right to veto, in the wake of Quebec's objections to the process surrounding the adoption of the procedures for constitutional amendment, the connection between the two was understood by many of Quebec's elite in precisely this way. The right to veto had been grounded in a theory of the Canadian federation that recognized Quebec as a founding partner, and a breach of those original understandings was thought to be so fundamental that it allowed Quebec to treat those arrangements as a nullity and to exit the constitutional order if it so chose.

The failure of the rules governing constitutional amendment becomes even clearer if we examine the federal stance regarding the applicability of the amending provisions to the secession of Quebec during the 1995 referendum. From the outset of the campaign, the federal government chose to focus on the substantive question of whether Quebec should remain within Canada and refused to be drawn into debates concerning the constitutional framework that governed the secession of a province from the Canadian federation. It made a conscious decision not to raise a constitutional challenge to Quebec's plan to issue a unilateral declaration of independence; it likewise refused requests that it refer the matter to the Supreme Court of Canada, and it chose not to intervene once constitutional litigation had been launched.

This decision not to raise constitutional issues reflected a calculation by the federal government that the political costs of doing so outweighed the possible benefits. One concern was that, by spelling out the procedure for secession, the federal government would make it more likely to happen. Another was the fear that any discussion of legal issues would be interpreted as a threat to use the Constitution to stand in the way of Quebecers' exercise of their right to self-determination and would be seen as an attempt to intimidate Quebecers. Moreover, it was understood that the fact the amending procedures had been adopted over Quebec's objection made matters even worse.

In addition, it is arguable that federal political actors did not raise the constitutional issue because even they may have concluded that legal processes could not restrain and regulate the constitutional politics of secession in the event of an attempt by Quebec to secede unilaterally. In a widely discussed and unscripted set of remarks, coming shortly after the release of the text of the Draft Bill on Sovereignty, the federal minister of justice, Allan Rock, acknowledged "[c]learly, there exists no provision in 
Canada's constitution" for Quebec to unilaterally secede from Canada, and he went on to say:

But I wonder whether that's the real question now. . . Is everyone interested in these technical details? ... To my mind, it's not constitutional [for a province to secede unilaterally] ... But that's a technical question. The real question is for Quebecers, in a referendum.... It's possible to have a debate on the constitutionality of (Parizeau's) draft legislationa very interesting (debate) for lawyers - but what matters more is the will of Quebecers. ${ }^{133}$

Although Rock was publicly corrected by the prime minister, ${ }^{134}$ the fact that the federal minister of justice would voice such a view suggests there was an understanding very early on, within some quarters of the federal government, that the procedures governing constitutional amendment might not operate in the secession context. A similar incident took place shortly before the hearing in the Secession Reference, when the federal minister of justice stated in a newspaper interview that "the existing constitutional framework" might not apply in the event of a "yes" vote. ${ }^{135}$ This position flatly contradicted the federal argument. The Court asked the federal government's lawyers to explain the comment. Chief counsel actually suggested, at first, that, in the event of the unworkability of secession under the rules governing constitutional amendment, "the Government of Canada would not stand in the way of a clear expression by the majority of Quebecers, a clear expression of its wish to secede from Canada"136 - suggesting that those rules could be put to one side.

Finally, the desire not to work within the procedures governing constitutional amendment continues in the judgment of the Court itself. Before setting out the secession clause, the Court accepted that secession could be achieved through constitutional amendment. ${ }^{137}$ However, this did not address the constitutionality of unilateral secession by Quebec. There were two possible ways for the Court to address this issue, both of which required the Court to grapple with the specifics of the rules. One way would have been to specify which amendments would be required, to consider the relevant amending procedures, and to determine whether any of these required the consent of the federal government. The other avenue open to the Court would have been to look

\footnotetext{
${ }^{133}$ Paul Wells \& Philip Authier, Sovereignty Law Illegal, Rock Says, MonTrEaL GazeITE, Dec. 16, 1994, at $\mathrm{A} 1$.

${ }^{134}$ Jim Brown, Not Our Job to Negotiate Split: PM, Montreal GazeTTE, Dec. 20, 1994, at A20.

${ }^{135}$ As quoted by former Chief Justice Lamer in his question to counsel for the Attorney General of Canada in oral hearing of the Reference re Secession of Quebec (Reference re Secession of Quebec, Transcription of Cassettes, Feb. 19, 1998, at 4).

${ }^{136}$ Id at 9.

${ }^{137}$ Reference re Secession of Quebec, [1998] 2 S.C.R. 217, at paras. 86-88.
} 
at the one amending procedure that allows unilateral constitutional amendment by a province, and to ask whether the internal limits of that provision rendered it inapplicable to secession. However, beyond stating that the amendments required "could be radical and extensive,"138 the Court did not suggest what specific amendments would be required.

Indeed, quite apart from failing to enumerate and interpret the amending procedures, the judgment does not even refer to the existence of these rules. This may have been a political judgment on the Court's part, reflecting the perceived illegitimacy of those procedures in Quebec. Had the Court framed its analysis of the constitutionality of unilateral secession around the procedures governing constitutional amendment, it could have deepened and prolonged the country's constitutional crisis, for the very reason that a principal political actor-the government of Quebec-would likely have refused to comply with it. Not surprisingly, the Court held that unilateral secession would be unconstitutional, not because it would contravene the procedures for constitutional amendment but because it would contravene constitutional principles. ${ }^{139}$

For the Secession Reference to count as a component of a constitutional moment, we must link the failure of the rules governing constitutional amendment to the Court's move to change the Canadian Constitution through extralegal means. The procedures for constitutional amendment were not only incapable of governing the process of Quebec's departure from Canada but neither could they be deployed to enact constitutional amendments that would have created a procedure into which secessionist politics could be channeled and that was more likely than the existing constitutional framework to be followed by the parties concerned. It is not hard to understand why. A round of constitutional politics focusing on the constitutional regulation of the process of secession, much like constitutional negotiations focused on secession itself, would have raised existential questions regarding the basic terms of political association of the Canadian political community. Although Canada has never had such a round of constitutional politics, any of the plausible alternatives that parties might have raised would themselves have involved an understanding of the very nature of Canada. For example, a constitutional ban on secession arguably reflects a political theory that holds that the entire territory of a country belongs to all of its citizens equally and, therefore, those citizens occupying a particular portion of the national territory would be violating the rights of fellow citizens through unilateral secession. Conversely, a constitutional right to secede could be premised on the opposite view, as Daniel Philpott has written; namely, that since membership in a political community is voluntary it must also include the right to withdraw from an existing political community and to construct a new one, and for this right to be meaningful it must

${ }^{138}$ Id. at para. 84.

${ }^{139}$ Id. at para. 91. 
encompass the right to a territory over which to exercise political control. ${ }^{140}$ Alternatively, a right to secede grounded in a theory of Canada as a multinational federation, with its constituent communities retaining the right to withdraw from the federal pact-would also reflect a concept of the Canadian political community. ${ }^{141}$

In short, just as the rules governing constitutional change reflect a vision of the ultimate locus of political sovereignty in a political community, so do the rules governing constitutional exit. A debate over what rules to adopt for secession would also have brought into question the rules governing constitutional amendment, which reflected one of the substantive conceptions on the table, rendering it incapable of providing the framework within which such a constitutional change could be debated.

\section{Moving forward: Constitutional moments in comparative perspective}

Ackerman reframes constitutional theory around the following problem: America's constitutional development contains many examples of fundamental and dramatic constitutional changes that appear to have occurred outside the textually prescribed procedures for constitutional amendment. Constitutional theory, therefore, must come to terms with illegal constitutional change - why and how it has occurred, and what challenges, if any, it presents for the legitimacy of the contemporary American constitutional order. Although his descriptive account of higher lawmaking is unsuccessful, Ackerman has posed the right question.

A careful analysis of Ackerman's account of Reconstruction and the country's founding suggests that he believes that constitutional moments, in reality, are moments of constitutional failure and paralysis. Moreover, constitutional moments travel and shed considerable light on comparable developments in other constitutional systems. The decision of the Canadian Supreme Court in the Secession Reference is best understood as part of a constitutional momentan extralegal move to amend the Canadian Constitution to add a secession clause, prompted by the failure of the rules for constitutional amendment under the Constitution. Those rules failed because they reflected a conception of the Canadian political community that the Quebec sovereignty movement challenged, treating Quebec as one province among many and granting a veto to the federal government. Indeed, much of the history of Canadian constitutional politics has turned on the search for an acceptable formula for constitutional amendment and has been hotly contested precisely because it was

\footnotetext{
${ }^{140}$ Daniel Philpott. In Defence of Self-Determination, 105 ETHICs 352 (1995).

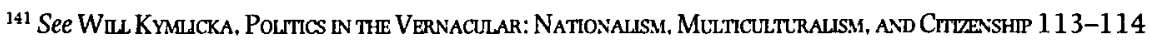
(Oxford Univ. Press 2001).
} 
understood that the resulting rules would reflect a specific conception of Canada. Instead of providing a stable and uncontested framework for constitutional politics, those rules were drawn into constitutional politics and were unable to perform their basic function. This deep and profound constitutional failure offers a new explanation for the Court's otherwise puzzling move to amend the Canadian Constitution extralegally to add procedures for secession under the guise of constitutional interpretation - a move it made because the formal rules for constitutional change could not yield such a change.

The comparative constitutional research agenda should be to use the reinterpreted concept of the constitutional moment to study dramatic constitutional changes in other jurisdictions. Scholars of comparative constitutionalism must identify moments of constitutional change that appear to have occurred outside normal constitutional processes for constitutional amendment. They should then determine whether those episodes are best understood as moments of constitutive constitutional politics that the rules governing constitutional amendment were unable to regulate. A promising source of examples might be the process of decolonization of former British colonies. Those colonies typically were granted independence through acts of the British Parliament that created postindependence constitutions. These were often followed, however, by "paper" constitutional coups that involved the adoption of new constitutions by domestic political institutions in contravention of those postindependence constitutions. ${ }^{142}$

The reason for these unconstitutional acts of constitution making may be found in the view that the status of postindependence constitutions as imperial statutes meant that the colonies were exercising delegated powers from Britain. In theory, these delegated powers could be withdrawn because Parliament retained ultimate sovereignty, which it could not by its very nature surrender. The theoretical possibility of imperial repeal, in effect, was a rule governing constitutional amendment, embodying an understanding of political community that was fundamentally at odds with the existence of a sovereign political entity. As a consequence, postindependence constitutions could not serve as a legitimate basis for regulating constitutional change, and political actors in newly independent states discarded them. The goal was to establish an autochthonous source of constitutional title through an extralegal act that is best understood as a moment of constitutive constitutional politics.

Comparative investigation potentially also could yield dividends for the understanding of American constitutional development. The Canadian example clearly illustrates how the rules of constitutional amendment were a central part of the history of Canadian constitutional politics. The comparative research question for American constitutional scholars is to focus more

${ }^{142}$ John Finnis. Revolutions and Continuity of Law, in OXFoRd Essays IN JURISPRUDENCE: SECOND SERIES 64 (A.W.B. Simpson ed., Oxford Univ. Press 1973). 
squarely and intensely on why political actors opted to proceed outside the formal rules for constitutional amendment. In light of the Canadian example. the materials surrounding the gaming of article 5 during Reconstruction and the Articles of Confederation during the founding may warrant revisiting with this comparatively oriented question in mind.

Finally, the reinterpretation of constitutional moments as constitutional failures at moments of constitutive constitutional politics furthers Ackerman's agenda for constitutional design (albeit in a manner he may not appreciate). Rules governing constitutional amendment are an indispensable aspect of constitutional design. They are an important device for ensuring the relevance and, hence, both the legitimacy and stability of a constitutional order, so much so that the failure of a constitution to include them or to make them too demanding to deploy would be a fundamental constitutional defect that could pose a threat to the survival of a constitutional system.

But there are limits to sound constitutional design. Rules for constitutional amendment face genuine difficulty in constituting and regulating moments of constitutive constitutional politics, because at those moments the very concept of political community, which those rules reflect, is at issue. Moreover, no matter how well designed, any set of rules governing constitutional amendment will have a limiting case of some sort-a moment of failure built into the very design of those rules. The true lesson of constitutional moments in comparative perspective may be an awareness of the limits on the ability of constitutional forms to regulate constitutional politics-and on the limits of constitutionalism itself. 